Jurnal Konstruksi Hukum | ISSN: 2746-5055

Vol. 2, No. 1, Januari 2021 Hal. 170-174 | Tersedia online di https://www.ejournal.warmadewa.ac.id/index.php/jukonhum

DOI: https://10.22225/jkh.2.1.2989.170-174

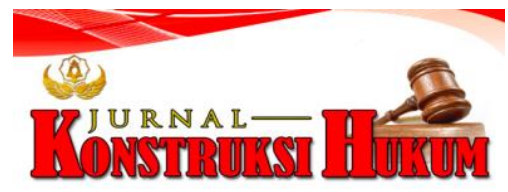

\title{
TRADISI MANAK SALAH DI DESA ADAT PADANGBULIA KECAMATAN SUKASADA KABUPATEN BULELENG
}

\author{
Ni Luh Gede Astari Dewi, I Ketut Sukadana, Diah Gayatri Sudibya \\ Fakultas Hukum Universitas Warmadewa, Denpasar-Bali, Indonesia
}

\begin{abstract}
Abstrak
Manak salah merupakan tradisi yang dilaksanakan oleh masyarakat adat Padangbulia yang menganggap bahwa kelahiran bayi kembar buncing (laki-laki dan perempuan) merupakan suatu kesalahan yang mewajibkan orang tua beserta bayi kembar buncing melakukan pengasingan sementara selama tiga bulan. Hal tersebut dianggap bertentangan dengan kemanusiaan sehingga pemerintah mengeluarkan Peraturan Daerah Nomor 10 Tahun 1951 tentang Penghapusan Adat Manak Salah atau Buncing. Penelitian ini bertujuan untuk menjelaskan tradisi manak salah di Desa adat Padangbulia dan apakah yang menjadi faktor-faktor penyebab dari pelaksanaan tradisi manak salah di Desa Adat Padangbulia. Penelitian yang digunakan adalah penelitian hukum empiris dengan pendekatan sosiologi hukum dan pendekatan kasus dengan mencermati peristiwa hukum yang nyata terjadi di Desa Padangbulia serta sumber bahan hukum yang digunakan adalah bahan hukum primer dan sekunder dengan teknik pengumpulan bahan hukum melalui wawancara dan pencatatan yang dianalisis secara kualitatif dalam bentuk deskriptif analisishasil penelitian menunjukkan bahwa Manak salah dilaksanakan sesuai dengan kepercayaan masyarakat Padangbulia dengan lontar dewa tatwa dan brahma sapa yang digunakan sebagai dasar pelaksanaan tradisi ini sejak dahulu kala. Meskipun telah dihapuskan tradisi manak salah masih dilaksanakan sampai saat ini karena kepercayaan masyarakat adat Padangbulia tentang bencana yang akan terjadi apabila tradisi ini tidak dilaksanakan.
\end{abstract}

Kata Kunci: Tradisi; Manak Salah; Kembar Buncing; Adat

\begin{abstract}
Manak salah is a tradition carried out by the Padangbulia indigenous people who consider that the birth of tapered twins (male and female) is a mistake which obliges the parents and the tapered twins to undergo temporary isolation for three months. This was considered contrary to humanity so that the government issued Regional Regulation Number 10 of 1951 concerning the Elimination of Manak Salah or Buncing Customs. This study aims to explain the manak salah tradition in the traditional village of Padangbulia and what are the factors causing the implementation of the manak salah tradition in the traditional village of Padangbulia. The research used is empirical legal research with a sociology of law approach and a case approach by looking at real legal events that occurred in Padangbulia Village and the sources of legal materials used are primary and secondary legal materials with techniques of collecting legal materials through interviews and recording which are analyzed qualitatively in The descriptive form of the analysis shows that Manak was wrongly implemented in accordance with the beliefs of the Padangbulia people with the palm-leafed god tatwa and brahma sapa which were used as the basis for the implementation of this tradition since time immemorial. Even though the manak salah tradition has been abolished, it is still being carried out today because of the belief of the Padangbulia indigenous people about the disasters that will occur if this tradition is not implemented.
\end{abstract}

Keywords: Tradition; Manak Salah; Buncing Twins; Custom

\section{PENDAHULUAN}

Interaksi sosial dimulai dari keluarga (ayah ibu dan anak-anak) keluarga dikembangkan melalui pernikahan. Pernikahan dapat terlaksana apabila terjalin hubungan cinta kasih antara laki-laki dan perempuan yang kemudian disahkan secara agama dan hukum. Menurut Subekti, (2013) Perkawinan adalah pertalian yang sah antara seorang pria dengan seorang wanita untuk waktu yang lama.

Ikatan perkawinan bukan semata-mata memenuhi hak dan kewajiban suami istri, harta bersama, kedudukan anak hak dan kewajiban orang tua, tetapi juga menyangkut hubungan-hubungan adatistiadat kewarisan kekeluargaan kewarisan dan ketetanggaan serta menyangkut upacara-upacara adat dan keagamaan (Es, 2008). Tujuan perkawinan dalam Undang-Undang Nomor 16 Tahun 2019 tentang Perubahan Atas Undang-Undang Nomor 1 Tahun 1974 tentang perkawinan dan hukum 
adat Bali memiliki tujuan yang sama yaitu untuk mendapatkan keturunan sebagai penerus kehidupan keluarga baik yang berupa hak maupun kewajiban

Dalam usaha untuk mendapatkan keturunan tentunya kemungkinan untuk mendapatkan keturunan bayi kembar buncing atau bayi kembar laki-laki dan perempuan juga sangat besar. Berdasarkan perspektif adat Bali hal ini merupakan hal yang wajar saja terjadi, namun ada beberapa Desa adat di Bali yang masih menganggap bahwa bayi kembar buncing merupakan suatu kesalahan Sehingga diharuskan menjalankan sebuah tradisi yang disebut dengan tradisi Manak Salah. Bayi kembar buncing yang terlahir di lingkungan kerajaan diyakini membawa berkah dan kesejahteraan, namun, bayi kembar buncing dikatakan sebagai manak salah bila terlahir dari masyarakat jabawangsa yang diyakini keberadaannya mendatangkan bencana (Dwipayana \& Artajaya, 2018).

Menurut Sukerti \& Ariani, (2018) Fungsi perkawinan beda wangsa di Bali adalah untuk menentukkan kasta sosial adanya pandangan bahwa wangsa golongan tri wangsa lebih tinggi derajatnya dibandingkan dengan derajat golongan jaba wangsa. Pelaksanaan sanksi adat berupa pengucilan bukan saja diakibatkan oleh tekanan dari peraturan Desa setempat namun dari kesadaran sendiri oleh orang tua bayi takut terkena kutukan buta kala atau setan sesuai mitos yang mereka yakini (Dewi, 2019). Tradisi manak salah dianggap sangat bertentangan dengan Hak Asasi Manusia dan oleh karena itu Pada tanggal 12 Juli 1951 DPRD Bali menetapkan Peraturan Daerah Nomor 10 Tahun 1951 tentang Penghapusan Adat Manak Salah atau Buncing. Penelitian ini bertujuan untuk menjelaskan tradisi manak salah di Desa adat Padangbulia dan apakah yang menjadi faktor-faktor penyebab dari pelaksanaan tradisi manak salah di Desa Adat Padangbulia

\section{METODE PENELITIAN}

Tipe penelitian yang digunakan adalah penelitian hukum empiris, dengan pendekatan masalah yang digunakan adalah pendekatan sosiologi hukum yaitu dengan memperhatikan sebab perkembangan serta efek dari tingkah laku sosial dan menggunakan pendekatan kasus (caseapproach) (Waluyo, 2002). Peneliti mencermati peristiwa hukum yang secara nyata terjadi di Desa Adat Padangbulia Kecamatan Sukasada Kabupaten Buleleng. Sumber data primer dalam penelitian ini diperoleh langsung dari lapangan dengan cara wawancara informan dan responden sedangkan bahan hukum sekunder yang digunakan dalam penelitian ini adalah Undang-Undang Dasar Negara Republik Indonesia Tahun 1945 Undang-Undang No. 39 Tahun 1999 tentang Hak Asasi Manusia Undang-Undang Nomor 16 Tahun 2019 tentang Perubahan atas Undang-Undang Nomor 1 Tahun 1974 tentang Perkawinan dan Peraturan Daerah Nomor 10 Tahun 1951 tentang Penghapusan Adat Manak Salah atau Buncing

\section{HASIL DAN PEMBAHASAN}

\section{Tradisi Manak Salah di Desa Adat Padangbulia}

Tradisi Manak Salah masih diwariskan secara turun-temurun dari masa ke masa tidak terlepas dari kepercayaan agama Hindu, kepercayaan wahyu diatmika atau sekala (dapat dilihat) dan niskala (tidak dapat dilihat).Tidak ada keterangan yang jelas tentang kapan tradisi manak salah mulai dilaksanakan tetapi masyarakat mempercayai bahwa tradisi tersebut sudah dilaksanakan sejak dahulu kala hal tersebut diperkuat dengan ditemukannya beberapa lontar yang memuat tentang tradisi manak salah. Salah satunya adalah lontar Dewa Tatwadan Brahma Sapa. Dalam lontar Brahma Sapa diceritakan awal mula bagaimana bisa terjadinya fenomena manak salah atau kembar buncing.

Sampai saat ini masyarakat padangbulia masih mempercayai hal tersebut dan oleh karena itu setiap ada kelahiran bayi kembar buncing, maka semua masyarakat akan saling menolong bergotong-royong untuk membantu segala hal yang harus dilakukan sesuai dengan isi dari lontar dewa tatwa. Lontar Dewa Tatwa dan Brahma Sapa yang berlaku di Desa adat Padangbulia merupakan dasar dari pelaksanaan upacara melasti terkait dengan kelahiran bayi kembar buncing atau manak salah. Masyarakat Padangbulia menganggap kelahiran bayi kembar buncing merupakan suatu kesalahan atau disebut sebagai salah wetu yang menyebabkan kahyangan menjadi kotor. Hal ini juga tercantum dalam lontar dewa tatwa yang berbunyi Yan ana salah wetu ring pasabhaning kahyangan yadnya sarwa tumuwuh manusa mwang sarwa patikawenang metu ring pertiwi manusa wetu tan pasuku tan pamata mwang ana lewihnia ana kurangnia wetu buncing mwah kunang sakalwir tan paripurna kadi kawitania yadyan sarba satwa yang berarti bahwa kahyangan yang 
disebut sebagai kahyangan kotor adalah bila ada kelahiran yang ganjil pada wilayah prahyangan seperti tumbuh-tumbuhan manusia dan segala hewan peliharaan yang lahir di bumi ini yaitu manusia lahir tanpa kaki tidak memiliki mata memiliki anggota tubuh yang berlebih ataupun yang kurang kelahiran buncing (laki-laki dan perempuan) dan semua kelahiran yang tidak sempurna termasuk binatang.

Dalam rangka menyucikan desa keluarga beserta bayi kembar buncing melakukan tapa berata atau pengasingan sementara di daerah campuhan selama telung tilem (tiga bulan). Selama masa pengasingan tersebut orang tua beserta bayi kembar buncing dilarang pulang ke rumah. Setelah tiga bulan tepatnya pada saat tilem ketiga orang tua beserta bayi kembar buncing akan melakukan rangkaian upacara penyucian yang akan dilakukan dibeberapa tempat yaitu dimulai di tempat tapa berata yang kemudian dilanjutkan di pura desa setelah di pura desa maka akan dilanjutkan di segara (pantai) setelah selesai di pantai maka orang tua beserta bayi kembar buncing akan diantar kembali pulang ke rumah

\section{Faktor-Faktor Penyebab dari Pelaksanaan Tradisi Manak Salah di Desa Adat Padangbulia}

Tradisi manak salah merupakan tradisi yang dianggap bertentangan dengan hak asasi manusia banyak masyarakat Indonesia yang mengemukakan pendapat mereka tentang tradisi ini. Berikut merupakan pendapat beberapa orang tentang tradisi manak salak. Kembar buncing memiliki ikatan yang kuat satu sama lain mereka dapat hidup berdampingan satu sama lain. Sebetulnya dibalik realitas yang terjadi di Desa adat Padangbulia bahwa kembar buncing membawa kesialan kembar buncing juga memiliki ikatan yang kuat satu sama lain mereka layak hidup tanpa stigma pembawa sial. (Aditya Triadi 2019). Sanksi pengucilan yang dialami keluarga kembar buncing merupakan pelanggaran hak asasi manusia kalau andai kata ada landasan filosofinya itu harus diuji dengan landasan filosofis yang dianut oleh Negara Indonesia setelah merdeka yakni falsafah pancasila. Jadi untuk mengganti sanksi pengucilan dengan sanksi baru yang sesuai falsafah pancasila sebagai cita hukum. Maka perlu dilakukan penelusuran sejarah munculnya manak salah yann merupakan suatu penghukuman yang tidak manusiawi terhadap orang yang tidak bersalah (Made, 2017).

Sebagian besar pendapat masyarakat umum menyatakan bahwa tradisi manak salah merupakan suatu pelanggaran hak asasi manusia dan sudah tidak layak lagi untuk diterapkan tetapi lain dengan masyarakat setempat yang menjalankan tradisi ini. Bapak Sadya Utama selaku masyarakat yang pernah menjalankan tradisi manak salah menjelaskan tidak ada paksaan dalam menjalankan tradisi ini bahkan beliau mengaku senang karena selama menjalankan tradisi beliau dilayani layaknya seorang raja. Beliau sangat berterimakasih kepada seluruh masyarakat padangbulia yang telah membantu beliau selama menjalankan tapa brata (I Gede Sadya Utama 2019).

Pengakuan dan perlindungan atas Hak Asasi Manusia (HAM) merupakan salah satu ciri dari Negara hukum. Hak Asasi Manusia merupakan hak dasar yang melekat pada individu sejak lahir dan merupakan pemberian dari Tuhan Yang Maha Esa yang tidak dapat dirampas dan dicabut keberadaannya dan wajib dihormati dan dilindungi oleh Negara (Arrasjid, 2000). Hak Asasi Manusia sebagiamana dikatakan diatas eksistensinya bukan karena diberikan oleh Negara hukum atau oleh manusia lain tetapi HAM dimiliki manusia semata-mata karena ia manusia (Satjipto, 2000). Bicara tentang tradisi manak salah tentu tidak terlepas dari hak asasi manusia banyaknya pendapat yang menyatakan bahwa tradisi ini bertentangan dengan hak asasi manusia yang menurut sebagian orang harus dihapuskan. Dalam pemikiran masyarakat lokal jika ada kelahiran bayi kembar buncing maka kelahiran tersebut dianggap sebagai kelahiran yang tidak masuk akal karena mereka mempercayai manusia hanya akan melahirkan satu anak saja. Melahirkan dua bayi sekaligus dianggap sama dengan seekor hewan karena pada umumnya hewanlah yang dapat melahirkan lebih dari satu orang anak.

Dalam hukum positif Indonesia tidak ada peraturan yang menyatakan bahwa kelahiran bayi kembar buncing merupakan sebuah kesalahan karena melakukan perkawinan merupakan hak dari setiap masyarakat Indonesia dan memiliki keturunan merupakan tujuan dari sebuah perkawinan. Hal tersebut tercantum dalam Pasal 1 Undang-Undang Nomor 16 Tahun 2019 tentang Perubahan Atas Undang-Undang Nomor 1 Tahun 1974 tentang Perkawinan mencantumkan Perkawinan ialah ikatan lahir batin antara seorang pria dengan seorang wanita sebagai suami istri dengan tujuan membentuk keluarga (rumah tangga) yang bahagia dan kekal berdasarkan Ketuhanan Yang Maha Esa. Dalam hal ini tujuan membentuk rumah tangga yang dimaksud adalah membentuk suatu 
keluarga yang dimana dalam sebuah keluarga terdapat ayah ibu dan anak- anak. Pada pasal 3 ayat (3) Undang-Undang Nomor 39 Tahun 1999 tentang Hak Asasi Manusia menyatakan setiap orang berhak atas perlindungan hak asasi manusia dan kebebasan dasar manusia tanpa diskriminasi.

Jika dihubungkan dengan pasal di atas dapat dikatakan bahwa menjalankan tradisi ini merupakan sebuah diskriminasi terhadap bayi kembar buncing karena setelah kelahirannya mereka harus melakukan pengasingan dengan istilah tapa brata yang bertujuan untuk melakukan penyucian atau dengan kata lain kelahiran bayi kembar buncing ini dianggap sebagai sebuah kesalahan yang membuat kotor. Berlandaskan lontar Dewa Tatwa masyarakat Padangbulia percaya dengan melaksanakan tradisi manak salah dapat menciptakan perdamaian secara niskalanamun jika tradisi ini tidak dilaksanakan dipercaya bahwa akan tejadi hal-hal yang tidak diinginkan seperti yang telah dicantumkan pada lontar dewa tatwa. Lontar Dewa Tatwa menjelaskan jika terjadi kelahiran bayi kembar buncing dan tradisi manak salah tidak dilaksanakan maka akan terjadi hal-hal yang tidak diinginkan. Sampai saat ini belum pernah ada yang dapat membuktikan tentang kebenaran dari isi lontar tersebut. Meskipun telah dihapuskan melalui Peraturan Daerah pada tahun 1951 tradisi ini tetap dilaksanakan karena apa yang tercantum dalam peraturan tersebut dianggap tidak sesuai dengan kanyataan yang terjadi. Peraturan Daerah Nomor 10 Tahun 1951 tentang Penghapusan Adat Manak Salah atau Buncing yang menyatakan Memperhatikan bahwa beranak sekelamin (lakilaki dan perempuan) yang telah biasa disebutkan dalam adat bali hindu Beranak Salah yang biasa berlaku melulu mengenai golongan sudrawangsa saja karena menurut paham kuno Amanda-manda sang ratu dan memanesi negeri. Memperhatikan bahasa bayi yang baru lahir itu bersama ibu bapaknya harus dipindahkan dari rumahnya kehalaman kuburan atau perapatan selama 42 hari hal ini dipandang menyalahi perasaan peri kemanusiaan dan kesehatan. Mengingat pula bahwasanya setelah sampai pada waktunya orang tua bayi itu harus membuat upacara prayascita untuk desa yang banyak menelan biaya. Menimbang bahasa adat sebagai tersebut di atas tiada sesuai lagi dengan keadaan pada masa ini. Memutuskan menetapkan peswara penghapusan adat yang disebut manak salah atau buncing dihapuskan.

(1) Apabila ada orang yang melahirkan anak laki perempuan yang menurut adat Bali Hindu dulu disebut manak salah atau buncing maka setelah berlakunya peraturan ini orang-orang yang bersangkutan tiada dianggap bersalah dan tiada boleh dikenai hukuman apapun

(2) Dengan berlakunya peraturan ini adat yang disebut manak salah atau buncing dihapuskan

(3) Peraturan ini dapat disebut peraturan penghapusan adat manak salah atau buncing dan mulai berlaku pada hari diumumkannya.

Berdasarkan peraturan di atas masyarakat Padangbulia mengklaim bahwa apa yang mereka laksanakan tidak bertentangan dengan peraturan tersebut karena dalam peraturan tersebut dijelaskan bahwa

1. berlaku untuk golongan sudrawangsa saja

Dalam peraturan diatas disebutkan bahwa tradisi manak salah hanya berlaku untuk golongan sudrawangsa yaitu masyarakat biasa yang tidak berkasta atau dalam masa kerajaan disebut sebagai masyarakat bawah. Hal tersebut tidak benar karena di Desa adat Padangbulia setiap orang tua yang melahirkan bayi kembar buncing wajib melaksanakan tradisi manak salah tanpa terkecuali dan tanpa melihat dari kasta mana orang tersebut berasal

2. Bayi yang baru lahir itu bersama ibu bapaknya harus dipindahkan dari rumahnya kehalaman kuburan atau perapatan. Pada kenyataannya tempat menjalani tradisi manak salah bukanlah dihalaman kuburan sebagaimana dinyatakan dalam peraturan tersebut karena tradisi ini dilaksanakan jauh dari setra (kuburan bali) tradisi ini dilaksanakan di daerah campuhan (sungai tempat bertemunya beberapa sumber mata air yang berbeda).

3. Orang tua bayi itu harus membuat upacara prayascita untuk desa yang banyak menelan biaya. Segala biaya yang dikeluarkan untuk keperluan menjalankan tradisi manak salah dimulai dari pembuatan gubuk (rumah sementara) biaya yang dikeluarkan saat menjalankan tradisi seperti biaya makan kedua orangtua dan kebutuhan bayi serta biaya pengobatan jika sewaktu-waktu bayi atau orang tua bayi ada yang sakit dan biaya upacara setelah menjalankan tradisi ditanggung oleh desa adat padangbulia.

Berdasarkan hal-hal tersebut desa adat Padangbulia tetap menjalankan tradisi manak salah sesuai dengan lontar yang mereka percaya dan dengan anggapan bahwa apa yang mereka lakukan tidak 
sama dengan apa yang tercantum dalam Peraturan Daerah Nomor 10 Tahun 1951 tentang Penghapusan Adat Manak Salah atau Buncing sehingga muncul anggapan bahwa apa yang mereka lakukan bukanlah sebuah perbuatan melanggar hukum.

\section{SIMPULAN DAN SARAN}

1. Simpulan

Berdasarkan hasil analisis data dapat dsisimpulkan bahwa tradisi manak salah (kembar buncing) merupakan tradisi yang wajib dilaksanakan apabila terjadi kelahiran bayi kembar buncing karena kelahiran tersebut dianggap kotor. Manak salah dilaksanakan sesuai dengan kepercayaan masyarakat Padangbulia dengan lontar dewa tatwa dan brahma sapa yang digunakan sebagai dasar pelaksanaan tradisi ini sejak dahulu kala. Tradisi ini dilaksanakan dengan cara tapa brata yang dilakukan oleh bayi kembar buncing beserta orangtua bayi selama telung tilem (tiga bulan), yang kedua tradisi manak salah sebenarnya sudah dihapuskan melalui Peraturan Daerah Nomor 10 Tahun 1951 tentang Penghapusan Adat Manak Salah atau Buncing namun tradisi manak salah masih dilaksanakan sampai saat ini karena kepercayaan masyarakat adat Padangbulia akan menimbulkan bencana apa bila tradisi tidak dilaksanakan.

\section{Saran}

Dari hasil penelitian ini, peneliti memberi saran yaitu kepada masyarakat Padangbulia hendaknya berhenti menganggap bahwa kelahiran bayi kembar buncing disamakan seperti binatang karena hal tersebut merupakan anugrah dari Tuhan Yang Maha Esa dan seharusnya hukum adat yang sudah tidak sesuai dengan perkembangan zaman dapat dsesuaikan kembali sehingga tidak bertentangan dengan Pancasila, yang kedua Jangan mempercayai berita-berita tentang tradisi manak salah yang seakan menjatuhkan desa yang masih melaksanakannya tanpa melihat apa yang sebenarnya terjadi

\section{DAFTAR PUSTAKA}

Arrasjid, C. (2000). Dasar-Dasar Ilmu Hukum. Sinar Grafika.

Dewi, D. P. (2019). Simbol Kekuatan Adat-Istiadat Bali dalam Novel Incestkarya I Wayan Artika (Kajian Semiotika Budaya). 3(2), 54-67.

Dwipayana, I. K. A., \& Artajaya, G. S. (2018). Hegemoni Ideologi Feodalistis dalam Karya Sastra Berlatar Sosiokultural Bali. Jurnal Kajian Bali, 8(22), 84-104.

Es, A. (2008). Mengenal Adat Istiadat Hukum Adat di Indonesia. LPP UNS dan UNS Press.

Made, P. D. I. (2017). Metodologi Penelitian Hukum Normatif dalam Justifikasi Teori Hukum. Kencana.

Satjipto, R. (2000). Ilmu Hukum. Citra Aditya Bakti.

Subekti. (2013). Hukum Adat Indonesia dalam Yurisprudensi Mahkamah Agung. Bandung Alumni.

Sukerti, N. N., \& Ariani, I. G. A. A. (2018). Budaya Hukum Masyarakat Adat Bali Terhadap Eksistensi Perkawinan Beda Wangsa. Jurnal Magister Hukum Udayana (Udayana Master Law Journal), 7(4), 516-528. Waluyo, B. (2002). Penelitian Hukum Praktek. Sinar Grafika. 